\title{
OPTICAL CROP SENSOR FOR VARIABLE-RATE NITROGEN FERTILIZATION IN CORN: II - INDICES OF FERTILIZER EFFICIENCY AND CORN YIELD ${ }^{(1)}$
}

\author{
Jardes Bragagnolo $^{(2)}$, Telmo Jorge Carneiro Amado(3), Rodrigo da Silveira Nicoloso(4), \\ Antônio Luis Santi ${ }^{(5)}$, Jackson Ernani Fiorin ${ }^{(6)}$ \& Fabiano Tabaldi ${ }^{(7)}$
}

\begin{abstract}
SUMMARY
Generally, in tropical and subtropical agroecosystems, the efficiency of nitrogen $(\mathrm{N})$ fertilization is low, inducing a temporal variability of crop yield, economic losses, and environmental impacts. Variable-rate $\mathrm{N}$ fertilization (VRF), based on optical spectrometry crop sensors, could increase the $\mathrm{N}$ use efficiency (NUE). The objective of this study was to evaluate the corn grain yield and $\mathrm{N}$ fertilization efficiency under VRF determined by an optical sensor in comparison to the traditional single-application $\mathrm{N}$ fertilization (TSF). With this purpose, three experiments with no-tillage corn were carried out in the 2008/09 and 2010/11 growing seasons on a Hapludox in South Brazil, in a completely randomized design, at three different sites that were analyzed separately. The following crop properties were evaluated: aboveground dry matter production and quantity of $\mathrm{N}$ uptake at corn flowering, grain yield, and vegetation index determined by an N-Sensor ${ }^{\circledR}$ ALS optical sensor. Across the sites, the corn $\mathrm{N}$ fertilizer had a positive effect on corn $\mathrm{N}$ uptake, resulting in increased corn dry matter and grain yield. However, $\mathrm{N}$ fertilization induced lower increases of corn grain yield at site 2 , where there was a severe drought during the growing period. The VRF defined by the optical crop sensor increased the apparent $N$ recovery (NRE) and agronomic efficiency of $N$ (NAE) compared to the traditional fertilizer strategy. In the average of sites 1 and 3, which were not affected by
\end{abstract}

(1) Part of the first author's Masters Dissertation. Received for publication on December 11, 2012 and approved on July 11, 2013.

(2) Doctoral student in Soil Science, UFSM. Av. Roraima, 1000. CEP 97105-900 Santa Maria (RS), Brazil. E-mail: jardesb@yahoo.com.br

(3) Full Professor at the Department of Soil Science, UFSM. CNPq scholarship. E-mail: telmo.amado@pq.cnpq.br

(4) Researcher at Embrapa Swine and Poultry. Caixa Postal 21. CEP 89700-000 Concórdia (SC), Brazil. E-mail: rodrigo.nicoloso@embrapa.br

(5) Adjunct Professor in Centro de Educação Superior Norte do Rio Grande do Sul - CESNOR, UFSM. Linha Sete de Setembro, s/n, BR 386 Km 40. CEP 98400-000 Frederico Westphalen (RS), Brazil. E-mail: santi_pratica@yahoo.com.br

(6) Researcher at Foundation Center of Experimentation and Research, FUNDACEP-CCGL TEC. Professor at Cruz Alta University, UNICRUZ. Road RS 342 Km 149. CEP 98100-970 Cruz Alta (RS), Brazil. E-mail: jackson.fiorin@ccgl.com.br

(7) Master student in Precision Agriculture, UFSM. E-mail: fabianotabaldi@yahoo.com.br 
drought, VRF promoted an increase of 28.0 and $41.3 \%$ in NAE and NRE, respectively. Despite these results, no increases in corn grain yield were observed by the use of VRF compared to TSF.

Index terms: nitrogen, N-Sensor, optical spectrometry, precision farming.

\title{
RESUMO: SENSOR ÓPTICO NA FERTILIZAÇAO NITROGENADA À DOSE VARIÁVEL NO MILHO: II - ÍNDICES DE EFICIÊNCIA DA FERTILIZAÇÃO E PRODUTIVIDADE DE GRÃOS DE MILHO
}

\begin{abstract}
Geralmente, em agroecossistemas tropicais e subtropicais, a eficiência da fertilização nitrogenada para culturas agrícolas anuais é baixa, o que promove variabilidade temporal na produtividade das culturas, perdas econômicas e impacto ambiental. A fertilização à dose variada de nitrogênio (VRF) com base em sensores de culturas por espectrometria óptica pode aumentar a eficiência de uso do nitrogênio (NUE). Este estudo teve o objetivo de avaliar a produtividade do milho e a eficiência da VRF prescrita por um sensor óptico, em comparação com a fertilização à dose uniforme de nitrogênio (TSF). Com este propósito, três experimentos com milho sob sistema plantio direto foram conduzidos durante as safras agrícolas 2008/09 e 2010/11 sobre um Latossolo do sul do Brasil. O experimento foi conduzido em delineamento inteiramente casualizado, com cada local sendo analisado isoladamente. Os seguintes atributos foram avaliados: produção de matéria seca, acúmulo de $N$ na biomassa no pleno florescimento do milho, produtividade de grãos de milho e índice de vegetação (VI) medido pelo sensor óptico $N$-Sensor ${ }^{\circledR} A L S$. Independentemente do local investigado, a fertilização nitrogenada incrementou a quantidade de Nabsorvido pelas plantas, resultando em incremento da produção de matéria seca e da produtividade de milho. Os menores incrementos na produtividade de milho foram observados na área 2, que apresentou déficit hídrico em estádio fenológico crítico. A VRF aumentou a eficiência de recuperação aparente de $N(N R E)$ e a eficiência agronômica do uso de NAE pelo milho. Nas áreas 1 e 3, que não foram interferidas pela restrição hídrica, verificaram-se aumentos de 28,0 e 41,3\% na NAE e NRE, respectivamente, promovido pela $V R F$, em relação à TSF. Apesar desses resultados, não foi verificado aumento de produtividade do milho pelo uso da VRF, em comparação a TSF.
\end{abstract}

Termos de indexação: nitrogênio, $N$-Sensor, espectrometria óptica, agricultura de precisão.

\section{INTRODUCTION}

The average Brazilian corn grain yield is around 4.2 $\mathrm{Mg} \mathrm{ha}^{-1}$, far below the 10 to $15 \mathrm{Mg} \mathrm{ha}^{-1}$ recorded in rainfed croplands with intensive use of technology in the main Brazilian agroecoregions (Glat, 2010). According to the projections, the corn grain demand for animal feed will increase by $37 \%$ between 2005 2015 (Brasil, 2007). To attend this demand, corn grain yield should increase by $3.4 \%$ per year in the same period.

Corn grain yield depends on the quality of the crop management, especially nitrogen $(\mathrm{N})$ fertilization. Worldwide, the $\mathrm{N}$ fertilization efficiency is low (33\%) (Raun \& Johnson, 1999). This situation is aggravated in tropical and subtropical agroecosystems, where $\mathrm{N}$ losses can range from 18 to $78 \%$ of the $\mathrm{N}$ mineral fertilizer input (Lara Cabezas et al., 1997a; Fontoura \& Bayer, 2010; Rojas et al., 2012).

The main causes for the low efficiency of corn $\mathrm{N}$ fertilization are: high losses by $\mathrm{N}-\mathrm{NH}_{3}$ volatilization (Lara Cabezas et al., 1997b; Cantarella et al., 2008), $\mathrm{N}-\mathrm{NO}_{3}$ - leaching (Sangoi et al., 2003; Ceretta et al., 2005), lack of synchrony between crop demand and N availability (Amado et al., 2002; Aita \& Giacomini, 2008 ), inter-annual variability in the crop response to $\mathrm{N}$ fertilization (Fiorin et al., 2007; Ciampitti \& Garcia, 2008 ), and spatial variability of soil organic matter (SOM) and N mineralization potential (Shahandeh et al., 2005; Gregoret et al., 2006; Solie et al., 1999; Casa et al., 2011; Portz et al., 2012). All these factors influence $\mathrm{N}$ fertilization, making an increase in fertilizer use efficiency a complex challenge.

$\mathrm{N}$ fertilization recommendations for corn in Southern Brazil are based on the following parameters: soil organic matter (SOM) content, previous crop, and target grain yield, resulting in a TSF for a cropland (Amado et al., 2002; CQFSRS/SC, 2004). However, climatic conditions can affect soil $\mathrm{N}$ availability (Bragagnolo et al., 2013), crop residue input (Amado et al., 2002), and corn N use efficiency (NUE) (Melchiori et al., 2005), resulting in temporal variability of the crop $\mathrm{N}$ requirements. Consequently, the crops will require adjustments of the $\mathrm{N}$ fertilization strategy during the season (Melchiori et al., 2005; Singh et al., 2006).

The use of VRF is based on the spatial variability of the crop nutrition status in the field. Typically, there is a decrease in $\mathrm{N}$ fertilizer rate at sites where 
the cropland is already well nourished and on the other hand $\mathrm{N}$ rates are raised where the plants are undernourished. Thus, the $\mathrm{N}$ fertilizer efficiency is increased (Raun et al., 2005; Singh et al., 2006; Li et al., 2010), promoting higher economic revenue at a lower environmental impact (Gregoret et al., 2006). When $\mathrm{N}$ fertilization rates exceed the crop demand, they can increase the soil $\mathrm{N}-\mathrm{NO}_{3}$ content and therefore increase the risk of $\mathrm{N}$ losses through denitrification (Fernandes \& Libardi, 2007; Escobar et al., 2010) or leaching (Sangoi et al., 2003; Ceretta et al., 2005; Fernandes \& Libardi, 2007).

The use of real-time crop sensors, by which the plant nutritional status can be indirectly estimated, represents an innovation in $\mathrm{N}$ fertilization (Argenta et al., 2003; Raun et al., 2005; Berntsen et al., 2006; Portz et al., 2012). Among the optical sensors commercially available, the Yara N-Sensor ${ }^{\circledR}$ ALS (Yara International ASA) has been used successfully in different crops (Jasper et al., 2009; Portz et al., 2012; Bragagnolo et al., 2013).

Previous studies addressing the efficiency of this sensor show increases in cereal yield from 3 to $13 \%$ over TSF, reduced crop lodging, increase of combine efficiency, improvement in grain protein content, and NUE (Singh et al., 2006). The increase in NUE could promote the reduction of $\mathrm{N}$ fertilizer input by $14 \%$ without impairing grain yield. This is a relevant achievement from the economic and environmental point of view (Singh et al., 2006). Apart from fertilization, this optical sensor has been used for objectives such as providing supplementary information for crop yield maps and prescriptions of agrochemical input (Singh et al., 2006).

Research with $\mathrm{N}$ fertilization based real-time crop sensors is still emerging in Brazil. The objective of this study was to evaluate the effect of VRF prescribed by an optical sensor in comparison to the traditional single-rate $\mathrm{N}$ fertilization (TSF) on corn grain yield and NUE in South Brazil.

\section{MATERIAL AND METHODS}

The treatments, experimental design, site locations, soil, and climate characteristics were previously reported in Bragagnolo et al. (2013).

\section{Corn grain yield}

Corn grain yield was assessed on the basis of corn cobs collected from $2 \mathrm{~m}$ in two rows of corn close to the georeferenced sampling points, where the plant vegetative properties were evaluated (Bragagnolo et al., 2013). Grain yield samples were collected at nine georeferenced points per treatment (distance of $40 \mathrm{~m}$ between each plot) at site 1 , while at site 2 samples were collected at 12 georeferenced points per treatment (distance of $20 \mathrm{~m}$ between each plot), and at site three samples were collected at seven georeferenced points per plot (distance of $40 \mathrm{~m}$ between plots). Results were adjusted to a grain moisture content of $13 \%$.

\section{Nitrogen use efficiency indices}

The NUE was calculated by the equations suggested by Dobermann (2005):

$$
\mathrm{PFP}=\mathrm{Y}_{\mathrm{N}} / \mathrm{X}_{\mathrm{N}}
$$

where $\mathrm{PFP}=$ partial factor productivity $\left(\mathrm{kg} \mathrm{kg}^{-1}\right.$ of grain by $\mathrm{N}$ input); $\mathrm{Y}_{\mathrm{N}}=$ grain yield of a given treatment with $\mathrm{N}$ fertilization (kg ha-1 of grain); and $\mathrm{X}_{\mathrm{N}}=$ quantity of $\mathrm{N}$ fertilizer input ( $\mathrm{kg} \mathrm{ha}^{-1}$ of $\left.\mathrm{N}\right)$.

$$
\mathrm{NAE}=\left(\mathrm{Y}_{\mathrm{N}}-\mathrm{Y}_{\mathrm{C}}\right) / \mathrm{X}_{\mathrm{N}}
$$

where $\mathrm{NAE}=\mathrm{N}$ agronomic efficiency $\left(\mathrm{kg} \mathrm{kg}^{-1}\right.$ of grain by $\mathrm{N}$ input); $\mathrm{Y}_{\mathrm{N}}=$ grain yield in treatment with $\mathrm{N}$ fertilization ( $\mathrm{kg} \mathrm{ha}^{-1}$ of grain); $\mathrm{Y}_{\mathrm{C}}=$ grain yield in control treatment (without $\mathrm{N}$ fertilization) $\left(\mathrm{kg} \mathrm{ha}^{-1}\right.$ of grain); and $\mathrm{X}_{\mathrm{N}}=\mathrm{N}$ fertilization $\left(\mathrm{kg} \mathrm{ha}^{-1}\right.$ of $\left.\mathrm{N}\right)$.

For site 1, where the control treatment had received starter $\mathrm{N}$ fertilization $\left(27 \mathrm{~kg} \mathrm{ha}^{-1}\right.$ of $\left.\mathrm{N}\right)$, this value was from the total $\mathrm{N}$ fertilization rate $\left(\mathrm{X}_{\mathrm{N}}\right)$ in the equation.

$$
\mathrm{NRE}=\left(\mathrm{NU}_{\mathrm{N}}-\mathrm{NU}_{\mathrm{C}}\right) / \mathrm{X}_{\mathrm{N}}
$$

where $\mathrm{NRE}=\mathrm{N}$ apparent recovery efficiency $\left(\mathrm{kg} \mathrm{kg}^{-1}\right)$; $\mathrm{NU}_{\mathrm{N}}=\mathrm{N}$ uptake in the treatment with $\mathrm{N}$ fertilization $\left(\mathrm{kg} \mathrm{ha}^{-1}\right) ; \mathrm{NU}_{\mathrm{C}}=\mathrm{N}$ uptake in the control treatment (without $\mathrm{N}$ fertilization) $\left(\mathrm{kg} \mathrm{ha}^{-1}\right) ; \mathrm{X}_{\mathrm{N}}=\mathrm{N}$ fertilization (kg ha $\left.{ }^{-1}\right)$.

For site 1, where the control treatment had received starter $\mathrm{N}$ fertilization $\left(27 \mathrm{~kg} \mathrm{ha}^{-1}\right.$ of $\left.\mathrm{N}\right)$, this value was from the total $\mathrm{N}$ fertilization rate $\left(\mathrm{X}_{\mathrm{N}}\right)$ in the equation.

$$
\mathrm{NPE}=\left(\mathrm{Y}_{\mathrm{N}}-\mathrm{Y}_{\mathrm{C}}\right) /\left(\mathrm{NU}_{\mathrm{N}}-\mathrm{NU}_{\mathrm{C}}\right)
$$

where NPE $=\mathrm{N}$ physiological efficiency $\left(\mathrm{kg} \mathrm{kg}^{-1}\right.$ of grain by $\mathrm{N}$ input); $\mathrm{Y}_{\mathrm{N}}=$ grain yield in treatment with $\mathrm{N}$ fertilization ( $\mathrm{kg} \mathrm{ha}^{-1}$ of grain); $\mathrm{Y}_{\mathrm{C}}=$ grain yield in control treatment (without $\mathrm{N}$ fertilization) $\left(\mathrm{kg} \mathrm{ha}^{-1}\right.$ of grain); $\mathrm{NU}_{\mathrm{N}}=\mathrm{N}$ uptake in treatment with $\mathrm{N}$ fertilization ( $\mathrm{kg} \mathrm{ha}{ }^{-1}$ of $\left.\mathrm{N}\right) ; \mathrm{NU}_{\mathrm{C}}=\mathrm{N}$ uptake in control treatment (without $\mathrm{N}$ fertilization) $\left(\mathrm{kg} \mathrm{ha}^{-1}\right.$ of $\left.\mathrm{N}\right)$.

The maximum technical efficiency (MTE) for $\mathrm{N}$ fertilization was assessed by adjusting mathematical functions between $\mathrm{N}$ fertilization rates and the relative grain yield for each site. The maximum economic efficiency (MEE) was assessed based on $90 \%$ of the MTE (Amado \& Mielniczuk, 2000).

The results were subjected to analysis of variance and descriptive statistical analysis. The means were compared by the Tukey test $(p<0.05)$, followed by polynomial regression analysis by using SISVAR 4.0 statistical software (Ferreira, 2000). The coefficient of variance (CV) of the optical sensor vegetation index (VI) was classified as low $(<12 \%)$, medium (12 to $62 \%$ ), or high ( $>62 \%$ ), as proposed by Warrick \& Nielsen (1980). 


\section{RESULTS AND DISCUSSION}

\section{Vegetation index and variable $\mathbf{N}$ fertilization rate estimated by the real-time crop sensor}

The high number of VI readings provided by the optical sensor reinforces the potential of this equipment for the prescription of VRF, promoting realtime information of the crop nutritional status with high spatial resolution, without requiring plant sampling and laboratory analysis (Table 1). The VI measurements covered around 40,30, and $33 \%$ of the total experimental corn fields at sites 1,2 , and 3 , respectively.

The occurrence of infield spatial variability in plant and soil properties is a prerequisite for the success of precision farming techniques (Saraiva et al., 2006; Povh \& Gimenez, 2011). Thus, when the spatial crop variability is high, the probability of success with the VRF strategy is greater. The corn VI spatial variability at the phenological stage V8 for the three areas is presented in figure 1 . The VI values at site 1 were about $50 \%$ lower than at the other sites (Table 2). Previously, Tremblay et al. (2009) and Soderstrom et al. (2010) also reported different VI values for the

Table 1. Variable nitrogen fertilization rate based on the crop optical sensor applied at the phenological stage V8 of corn

\begin{tabular}{lrrr}
\hline \multirow{2}{*}{ Experiment characteristic } & \multicolumn{3}{c}{ Location } \\
\cline { 2 - 4 } & Site 1 & Site 2 & Site 3 \\
\hline Strip width (m) & 15 & 20 & 18 \\
Strip length (m) & 380 & 260 & 300 \\
Velocity (km h ${ }^{-1}$ ) & 5 & 5 & 5 \\
Number of observations ha ${ }^{-1}$ & 254 & 310 & 297 \\
Sampled site (\%) & 40 & 30 & 33 \\
\hline
\end{tabular}

Table 2. Statistical parameters of variable-rate fertilization based on the optical sensor at the phenological stage V8 of corn

\begin{tabular}{|c|c|c|c|c|c|c|}
\hline \multirow{3}{*}{$\begin{array}{l}\text { Statistical } \\
\text { parameter }\end{array}$} & \multicolumn{6}{|c|}{ Location } \\
\hline & \multicolumn{2}{|c|}{ Site 1} & \multicolumn{2}{|c|}{ Site 2} & \multicolumn{2}{|c|}{ Site 3} \\
\hline & VI & NF & VI & NF & VI & NF \\
\hline & & $\mathrm{kg} \mathrm{ha}^{-1}$ & & $\mathrm{~kg} \mathrm{ha} \mathrm{H}^{-1}$ & & $\mathrm{~kg} \mathrm{ha}^{-1}$ \\
\hline Reference & 35.5 & 91.0 & 69.2 & 80.0 & 64.7 & 70.0 \\
\hline Minimum & 27.9 & 77.0 & 45.0 & 61.9 & 42.4 & 24.9 \\
\hline Maximum & 52.9 & 104.8 & 88.5 & 104.9 & 78.9 & 88.6 \\
\hline Mean & 35.5 & 89.9 & 69.2 & 79.4 & 64.7 & 70.7 \\
\hline Variance & 58.9 & 21.9 & 70.3 & 85.9 & 24.5 & 23.6 \\
\hline SD & 7.6 & 4.6 & 8.3 & 9.2 & 4.9 & 4.8 \\
\hline CV (\%) & 21.4 & 5.1 & 12.0 & 11.6 & 7.6 & 6.8 \\
\hline
\end{tabular}

VI: vegetation index; NF: estimated $\mathrm{N}$ fertilization rate; $\mathrm{SD}$ : standard deviation; CV: coefficient of variation. same corn phenological stage, according to the site and crop season.

In our study, the $\mathrm{CV}$ of the VI values ranged between 7 and $21 \%$ (Table 2), while Tremblay et al. (2009) reported CV for VI of 1 to $28 \%$. According to the classification proposed by Warrick \& Nielsen (1980), the CV of VI at sites 1 and 2 were classified as medium, while at site 3 the CV was low. Thus, according to the crop optical sensor, the first two sites had higher spatial corn variability as expressed by standard deviation (SD) and CV values in relation to site 3 (Table 2). These results could have been associated with the climatic conditions at site 3 , which were more favorable for corn growth, soil $\mathrm{N}$ mineralization, and plant $\mathrm{N}$ uptake than at the other sites (Bragagnolo et al., 2013).

The VI were lowest at site 1 (Table 2), at which the pluvial precipitation volume was highest until stage V8 (63.3\% of the total rainfall in the whole corn growing season), followed by days with low luminosity and cool temperature, which probably impaired corn $\mathrm{N}$ uptake. Frequent and intense precipitations increase $\mathrm{N}^{-} \mathrm{NO}_{3}{ }^{-}$leaching (Sangoi et al., 2003; Ceretta et al., 2005) and, as a consequence, reduce soil $\mathrm{N}$ availability to plants. Sites 2 and 3 had higher average VI values (Table 2). These results are coherent with the higher SOM content at sites 2 and $3(3.8 \%)$ in comparison to site 1 (2.8\%) (Bragagnolo et al., 2013).

The amplitude of $\mathrm{N}$ fertilization (NF) rates estimated by the optical sensor was lowest at site 1 , where the highest NF was 1.4 times higher than the lowest NF (Table 2). The higher amplitude of NF at sites 2 and 3 indicated a greater redistribution of $\mathrm{N}$ fertilizer along these plots. The ratio of the highest to the lowest NF at sites 2 and 3 was 1.7 and 3.6, respectively. These results could be explained by the lower VI amplitude (25.0) observed at site 1, in comparison to sites 2 (43.5) and 3 (36.5). Thus, $61 \%$ of the VI measurements at site 1 ranged between 22.6 and 30.6, suggesting low spatial plant variability (Figure 1). Yet at site 1, the corn plants produced least aboveground dry matter and took up least $\mathrm{N}$ in V8 of all three experimental sites (Bragagnolo et al., 2013). This result suggests that the N nutrition status of the corn plants at site 1 was homogeneously poor.

Based on the crop nutritional status assessed by VI, the optical sensor estimated the NF rates. For each site, the average $\mathrm{VI}$ was used as reference $\mathrm{N}$ fertilization rate. Only data of the sites 2 and 3 are shown in Figure 2, due to data storage problems at site 1 . There was a linear adjustment between VI and NF rates, therefore for every unit of increase in VI there was a $1 \mathrm{~kg} \mathrm{ha}^{-1}$ decrease in the estimated NF rate (Figure 2).

\section{$\mathrm{N}$ fertilization rates estimated by real-time crop sensor}

The NF rates estimated by the optical sensor along the plots with lengths ranging from 260 to $380 \mathrm{~m}$ are presented in figure 3 . The VRF in this study was 

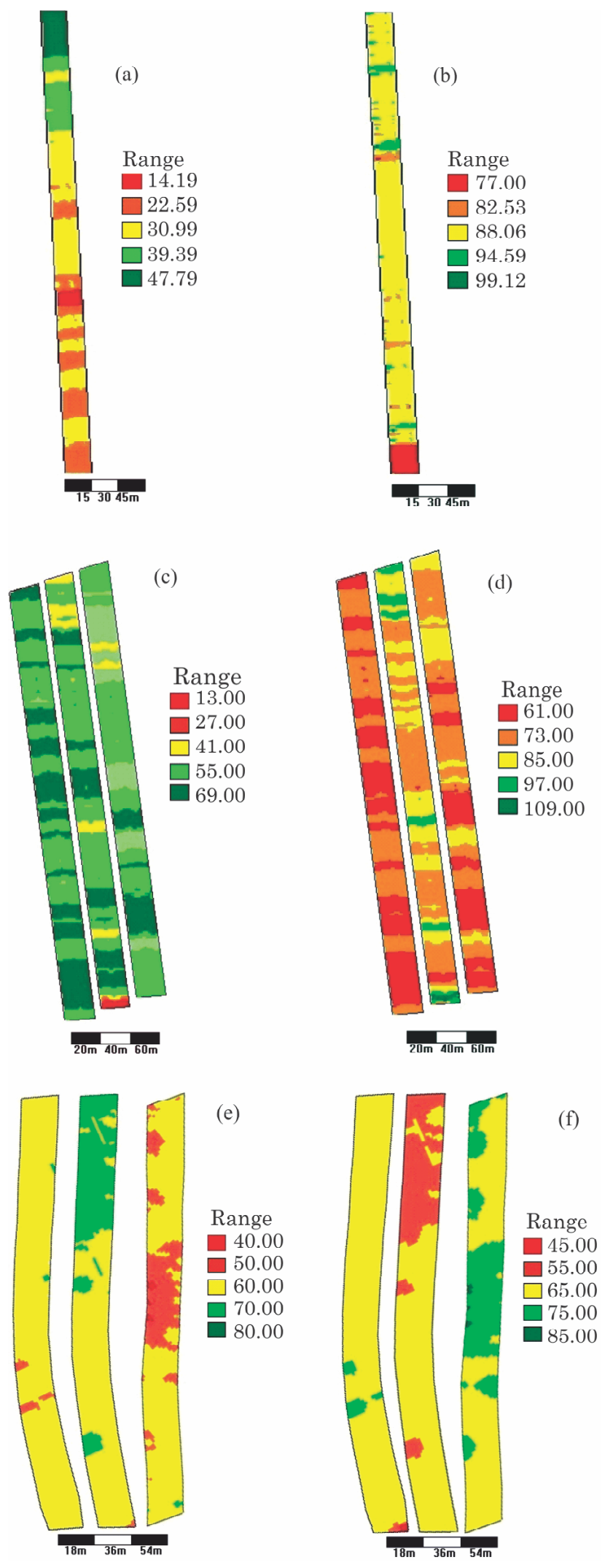

Figure 1. Vegetation index determined by the optical sensor at the phenological stage V8 of corn and the prescription of the variable-rate fertilization at sites $1(a, b), 2(c, d)$ and $3(e, f)$.

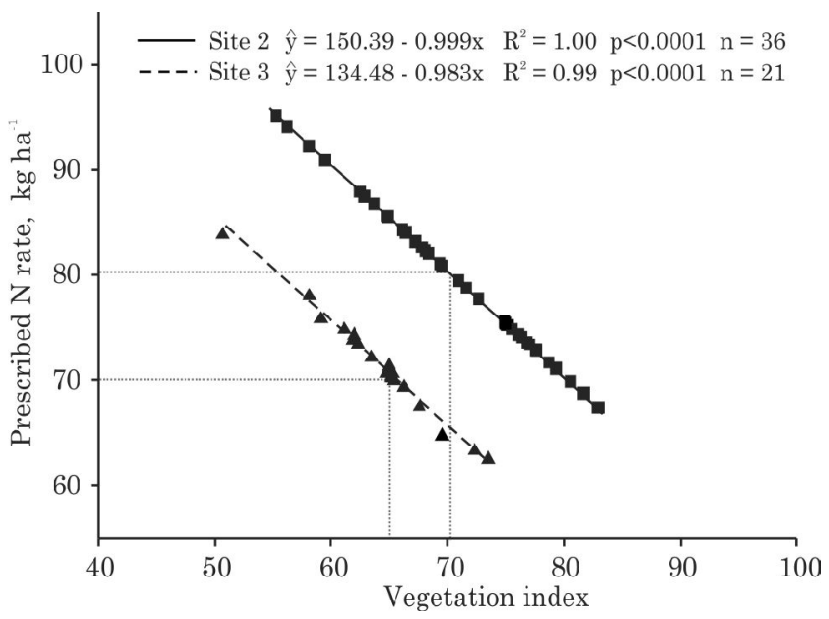

Figure 2. Nitrogen fertilization rate estimated by the optical sensor following the corn vegetation index at the phenological stage V8 for sites 2 and 3.
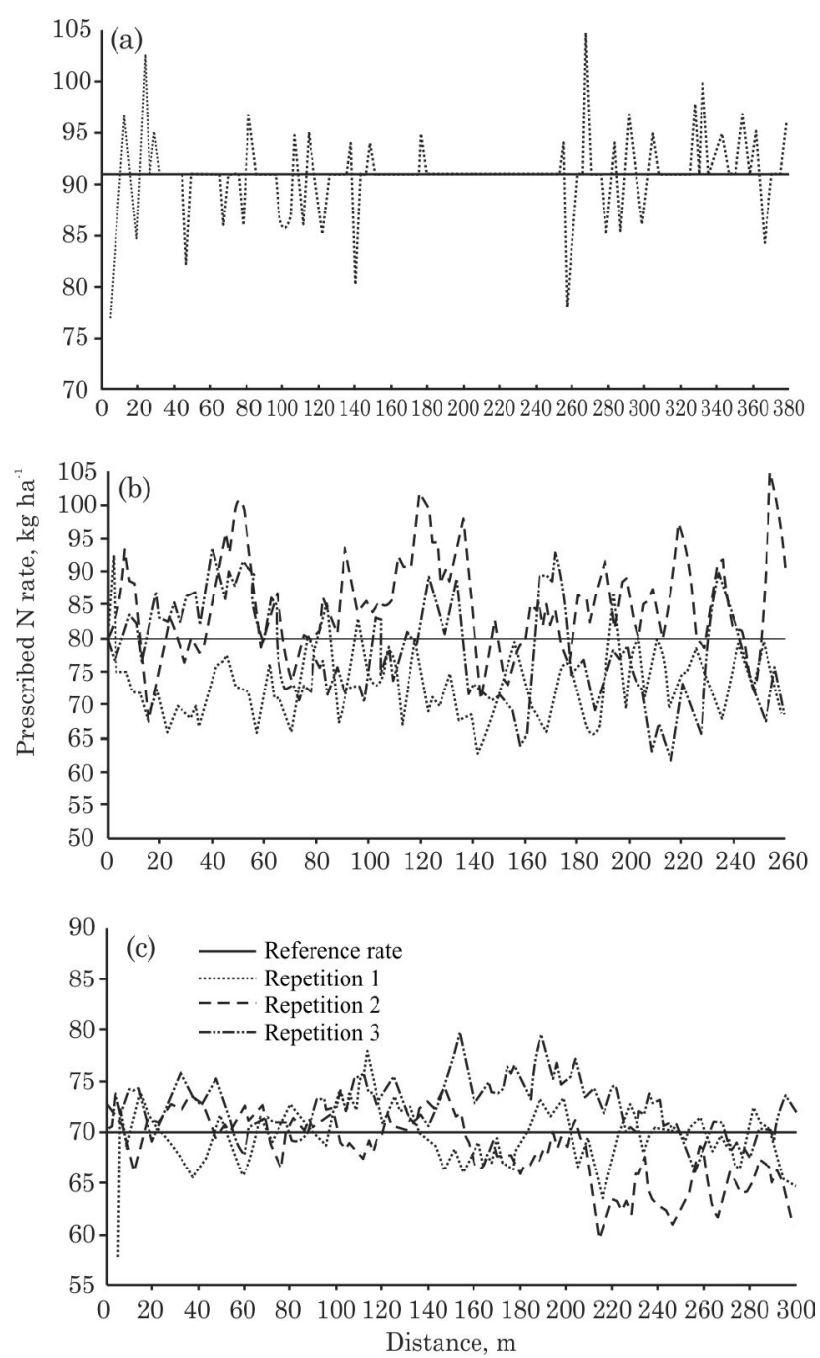

Figure 3. Variable nitrogen fertilization rates estimated by the optical sensor and the reference rate for (a) site $1\left(91 \mathrm{~kg} \mathrm{ha}^{-1}\right)$, (b) $2\left(80 \mathrm{~kg} \mathrm{ha}^{-1}\right)$, and (c) $3\left(70 \mathrm{~kg} \mathrm{ha}^{-1}\right)$. 
used only in the second topdressing fertilization (phenological stage V8) when the optical sensor was efficient to capture the corn nutrition status (Bragagnolo et al., 2013). For site 1 (without replication), $70 \%$ of the NF estimated by the optical sensor was coincident with the reference $\mathrm{N}$ fertilization rate $\left(91 \mathrm{~kg} \mathrm{ha}^{-1}\right)$, while 15.2 and $14.5 \%$ of the NF estimated was lower and higher, respectively. There was a long continuous series (between 170 and $250 \mathrm{~m}$ ), where the $\mathrm{N}$ fertilization rate applied was equal to the reference rate (Figure $3 a)$. This fact was due to a lack of GPS satellite signal reception, when the optical sensor automatically prescribed the reference rate (YARA, 2008).

At site 2, NF was estimated equal to the reference rate on only $7.7 \%$ of the site, while 55.5 and $36.8 \%$ of the remaining $\mathrm{NF}$ were below and above the reference rate, respectively. Under severe water stress (Bragagnolo et al., 2013), the spatial variability for VRF was highest at site 2, probably due to differences in soil water storage, since corn $\mathrm{N}$ uptake is strongly affected by plant water availability (Amado et al., 2002). The NF prescription at site 3 coincided in $9.7 \%$ with the reference $\mathrm{N}$ rate, while 36.9 and $53.4 \%$ of the site had $\mathrm{N}$ fertilization rates below and above the reference $\mathrm{N}$ rate, respectively.

\section{$\mathrm{N}$ fertilization relationships with corn plant nutrition and grain yield}

An analysis of the data across the three experimental sites showed a positive correlation between the quantity of corn $\mathrm{N}$ uptake at flowering with dry matter production $\left(R^{2}=0.76 ; p<0.0001\right)$ and grain yield $\left(R^{2}=0.68 ; p<0.0001\right)$ (Figure 4$)$.

Nitrogen uptake at corn flowering ranged from 31.1 to $182.6 \mathrm{~kg} \mathrm{ha}^{-1}$ in the different treatments and sites investigated, while corn dry matter production ranged from 5,500 to $12,200 \mathrm{~kg} \mathrm{ha}^{-1}$ and grain yield ranged from 5,403 to $15,564 \mathrm{~kg} \mathrm{ha}^{-1}$. Site 2 had the lowest $\mathrm{N}$ uptake and corn grain yield due to unfavorable climatic conditions (Bragagnolo et al., 2013). Site 3, which had the most favorable climatic conditions, showed the highest corn $\mathrm{N}$ uptake and corn grain yield of the three sites (Figure 4).

The corn grain yields at the experimental sites were similar to yields obtained by farmers who use advanced technology. The average grain yield for sites 1 and 2 (8,053 and 7,745 kg ha-1, respectively) was 96 and $89 \%$ higher, respectively, than the average grain yield in South Brazil $\left(4,100 \mathrm{~kg} \mathrm{ha}^{-1}\right)$ in the 2008/09 growing season (CONAB, 2009). The previous results were obtained in spite of a high precipitation volume during the initial stages of corn development (site 1), and a severe drought during the critical corn growth stages (site 2). The average grain yield at site 3 $\left(13,110 \mathrm{~kg} \mathrm{ha}^{-1}\right)$ was about three times higher than the average corn grain yield $\left(4,114 \mathrm{~kg} \mathrm{ha}^{-1}\right)$ in the 2010/11 season in Southern Brazil (CONAB, 2011). At this location, the high grain yield could be attributed to the good soil fertility, adequate rainfall, luminosity, and cool nights during the corn growth season. Farmers in the same season and region obtained average corn grain yields of $10,000 \mathrm{~kg} \mathrm{ha}^{-1}$ (Mânica, 2011).

$\mathrm{N}$ fertilization had a positive effect on corn grain yields, despite variations among the sites (Figure 5). The grain yields were lowest in the control treatments (without or with limited $\mathrm{N}$ fertilization), where grain yields were 57,65 , and $82 \%$ of the highest grain yield recorded at sites 1,3 , and 2 , respectively. The highest grain yields achieved in the trials were $15,564 \mathrm{~kg} \mathrm{ha}^{-1}$ for $210 \mathrm{~kg} \mathrm{ha}^{-1}$ of N at site $3,9,403 \mathrm{~kg} \mathrm{ha}^{-1}$ for $160 \mathrm{~kg} \mathrm{ha}^{-1}$ of $\mathrm{N}$ at site 1 , and $8,571 \mathrm{~kg} \mathrm{ha}^{-1}$ for $140 \mathrm{~kg} \mathrm{ha}^{-1}$ of $\mathrm{N}$ for site 2 .

The response in corn grain yield to $\mathrm{N}$ fertilization had similar patterns at sites 1 and 3 , where there was a linear increment of grain yield in response to NF rates (Figure 5a). Accordingly, the treatments 150VRF and 140VRF (see Table 2, part I) presented increments of 3,870 and $4,656 \mathrm{~kg} \mathrm{ha}^{-1}$ of grain yield in relation to the control treatment, at sites 1 and 3 , respectively, or 31.5 and $33.3 \mathrm{~kg} \mathrm{~kg}^{-1}$ of corn by $\mathrm{N}$ input, respectively (Table 3 ). However, corn grain yield at site 1 , in spite of having a high $\mathrm{N}$ fertilization rate
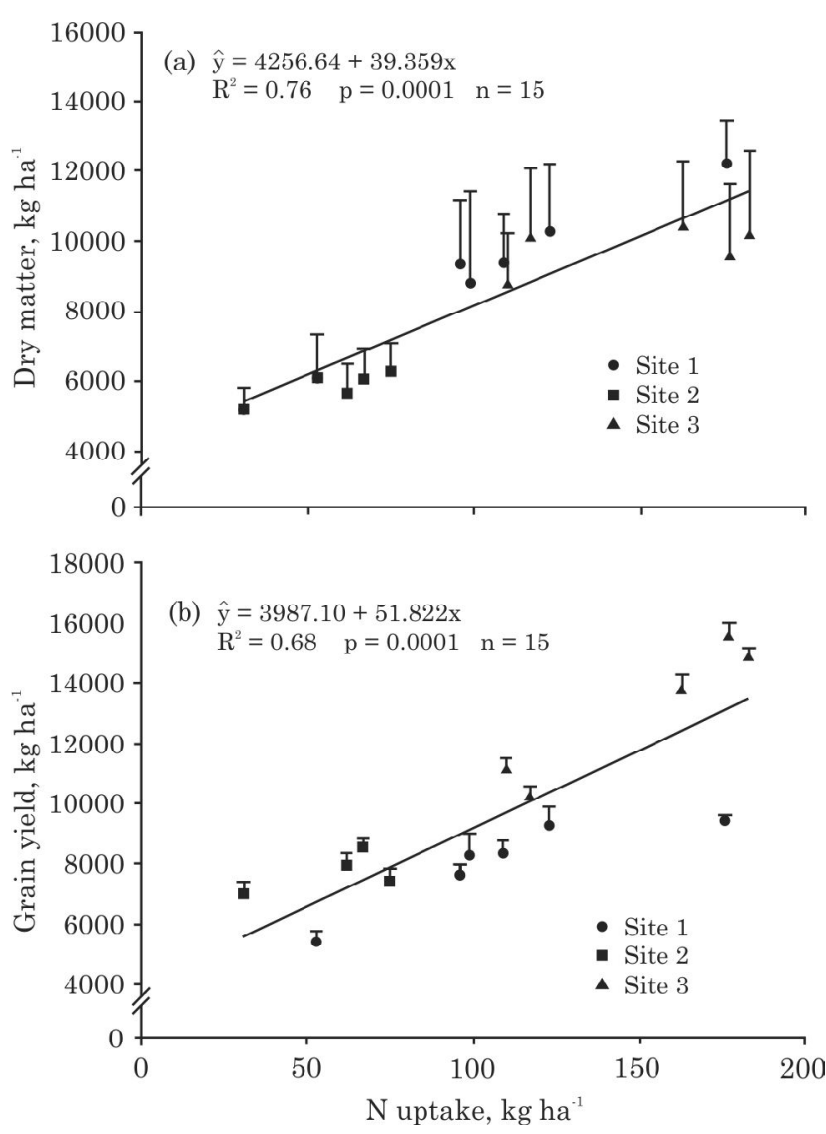

Figure 4. Relationships between corn $\mathrm{N}$ uptake at flowering and (a) corn dry matter, and (b) corn grain yield at the three investigated sites under $\mathrm{N}$ fertilizer rates. 
(140 kg ha-1 of N in TSF), was only $81 \%$ of the yield in the control treatment at site 3 .

The corn grain yield potential is defined in the early plant growing stages (Cantarella et al., 1993; Fancelli \& Dourado Neto, 1996). Thus, even though the corn $\mathrm{N}$ demand in the early growing stages is low (Gadioli et al., 2000), a high soil $\mathrm{N}$ availability is still required in that period to ensure high corn yields (Binder et al., 2000). The corn $\mathrm{N}$ uptake at the phenological stage V8 at site 1 was only $40 \%$ compared to that of site 3 (Bragagnolo et al., 2013). This result may have restricted corn grain yield at site 1 . At that site, the nutritional status of corn plants was recovered later and reached $71 \%$ of the amount of $\mathrm{N}$ uptake at flowering in relation to site 3 . However, corn grain yield at site 1 was only $61 \%$ of that verified at site 3 .

For site 2 , treatment $140 \mathrm{VRF}$ had a corn grain yield increase of $1,540 \mathrm{~kg} \mathrm{ha}^{-1}$ in relation to the control treatment, or $11 \mathrm{~kg}$ corn per $1 \mathrm{~kg}$ of $\mathrm{N}$ applied. This result should be analyzed, taking into account that the phenological stages with higher water demand are the periods of corn anthesis and milky grain stage. During these crop stages, evapotranspiration (ETP) is high and can range from 5.3 to $6.6 \mathrm{~mm}$ day $^{-1}$ (Matzenauer et al., 1995; Kang et al., 2003). However, water supply after anthesis at sites 1 and 2 was close
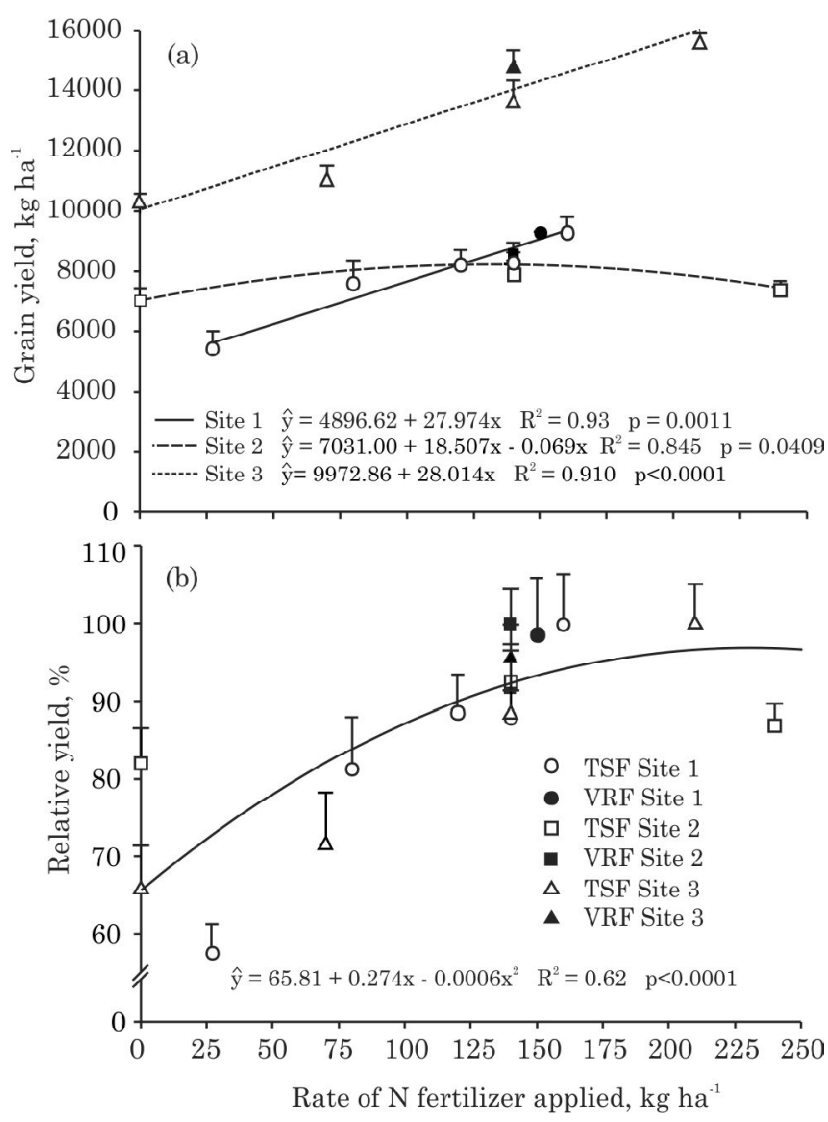

Figure 5. Relationships between $\mathbf{N}$ fertilization rates and (a) corn grain yield, and (b) relative corn grain yield at the three investigated sites. to 4.7 and $0.3 \mathrm{~mm} \mathrm{day}^{-1}$, respectively, indicating a severe hydric restriction at site 2 . Site 3 had an appropriate amount of water $\left(6.3 \mathrm{~mm} \mathrm{day}^{-1}\right)$ in the same period.

The average MTE of the three investigated sites was $228 \mathrm{~kg} \mathrm{ha}^{-1}$ of $\mathrm{N}$, while the maximum economic efficiency (MEE) was $125 \mathrm{~kg} \mathrm{ha}^{-1}$ of $\mathrm{N}$ (Figure 5b). Therefore, the NF rate selected to assess the VRF (140 kg ha ${ }^{-1}$ of N) was close to the MEE. Across the sites investigated, the corn grain yield was slightly higher in the optical sensor-based VRF treatments than when fertilization was based on the equations adjusted for TSF (Figure 5b). This result suggests that VRF was an efficient strategy for achieving higher yields with the same NF rate, although statistically there was no difference. Singh et al. (2006) reported that the use of optical sensors allows the maintenance of the grain yield level while reducing the NF rate. Furthermore, in our study the VRF treatments resulted in grain yields similar to those of the highest yield treatments achieved in each site (Figure 5a).

Based on the equations adjusted for grain yield as a function of NF rate, the corn yield of $9,093 \mathrm{~kg} \mathrm{ha}^{-1}$ at site 1 was estimated for a NF rate of $150 \mathrm{~kg} \mathrm{ha}^{-1}$ of $\mathrm{N}$ under TSF (Figure 5a). This calculation allowed the comparison of TSF and VRF at the same NF rate, showing that VRF increased corn grain yield by $2.0 \%\left(180 \mathrm{~kg} \mathrm{ha}^{-1}\right)$. The technical problems with the above-mentioned loss of the GPS signal probably contributed to the lower increase in corn yield than expected. However, at site 2 the same comparison showed that VRF increased corn grain yield by $8.05 \%\left(639 \mathrm{~kg} \mathrm{ha}^{-1}\right)$ in relation to TSF. This result was obtained in spite of the adverse climatic conditions registered at this site. The increase in corn grain yield promoted by VRF was coherent with the high redistribution of NF rate in this site (Figure 3). At site $3, \mathrm{VRF}$ increases in corn grain yield by $8.32 \%$ $\left(1,144 \mathrm{~kg} \mathrm{ha}^{-1}\right)$ were observed, in relation to TSF. On average, at the three investigated sites, the optical sensor-based VRF increased the corn grain yield by $6.12 \%\left(654 \mathrm{~kg} \mathrm{ha}^{-1}\right)$ in relation to TSF, yet this difference was not statistically significant (Table 3 ).

Previous comparisons of VRF and TSF showed wheat grain yield increases of 0.8 to $1.7 \%$ and protein content increases of 2.4 to $5.1 \%$ (Jørgensen \& Jørgensen, 2001, 2007; Mayfield \& Trengove, 2009). Raun et al. (2005) also observed slight increases in corn grain yield using another optical sensor $\left(\right.$ Greenseeker $^{\circledR}$ ) in relation to TSF, but with no statistical difference.

\section{$\mathrm{N}$ efficiency indices under different fertilizer strategies}

The corn $\mathrm{N}$ use efficiency (NUE) can be assessed by several indices, e.g., productivity partial factor (PFP), N agronomic efficiency (NAE), N recovery efficiency (NRE), and N physiological efficiency (NPE) (Dobermann, 2005). These indices are presented in 
Table 3. Nitrogen use efficiency according to nitrogen fertilization rates and fertilization at the three sites

\begin{tabular}{|c|c|c|c|c|c|c|}
\hline \multirow{2}{*}{ Site/treatment ${ }^{(1)}$} & \multicolumn{2}{|c|}{ Corn plant-technical property } & \multicolumn{4}{|c|}{ Efficiency index } \\
\hline & Grain yield & N uptake ${ }^{(2)}$ & PFP & NAE & NRE & NPE \\
\hline & $-\mathrm{kg}$ & - & & - & + & \\
\hline \multicolumn{7}{|l|}{ Site 1} \\
\hline $27 \mathrm{TSF}$ & $5403 \mathrm{~d}$ & $53 \mathrm{c}$ & 200 & - & - & - \\
\hline 80TSF & $7639 \mathrm{c}$ & $96 \mathrm{c}$ & 95 & 42 & 0.82 & 51 \\
\hline $120 \mathrm{TSF}$ & $8336 \mathrm{bc}$ & $109 \mathrm{~b}$ & 69 & 31 & 0.60 & 52 \\
\hline $140 \mathrm{TSF}$ & $8265 \mathrm{bc}$ & $99 \mathrm{~b}$ & 59 & 25 & 0.41 & 62 \\
\hline $150 \mathrm{VRF}$ & $9273 \mathrm{ab}$ & $123 \mathrm{~b}$ & 62 & 31 & 0.57 & 55 \\
\hline 160TSF & $9403 \mathrm{a}$ & $176 \mathrm{a}$ & 58 & 30 & 0.92 & 32 \\
\hline Mean & 8053 & 109 & 71 & 32 & 0.66 & 50 \\
\hline \multicolumn{7}{|l|}{ Site 2} \\
\hline Control & $7031 c$ & $31 \mathrm{c}$ & - & - & - & - \\
\hline 140TSF & $7932 \mathrm{ab}$ & $62 \mathrm{~b}$ & 57 & 6 & 0.22 & 13 \\
\hline $140 \mathrm{VRF}$ & 8571 a & $67 \mathrm{~b}$ & 61 & 11 & 0.25 & 43 \\
\hline 240TSF & $7445 \mathrm{bc}$ & $75 \mathrm{a}$ & 31 & 2 & 0.21 & 20 \\
\hline Mean & 7745 & 57 & 60 & 6 & 0.23 & 25 \\
\hline \multicolumn{7}{|l|}{ Site 3} \\
\hline Control & $10231 \mathrm{c}$ & $117 \mathrm{c}$ & - & - & - & - \\
\hline 70TSF & $11125 \mathrm{c}$ & $110 \mathrm{c}$ & 159 & $*$ & $*$ & $*$ \\
\hline $140 \mathrm{TSF}$ & $13743 \mathrm{~b}$ & $163 \mathrm{~b}$ & 98 & 25 & 0.32 & 71 \\
\hline 140VRF & $14887 \mathrm{ab}$ & $183 \mathrm{a}$ & 106 & 33 & 0.46 & 76 \\
\hline 210TSF & $15564 \mathrm{a}$ & $177 \mathrm{ab}$ & 74 & 25 & 0.42 & 88 \\
\hline Mean & 13110 & 153 & 117 & 27 & 0.40 & 78 \\
\hline
\end{tabular}

(1) For the treatments, see Part I; ${ }^{(2)} \mathrm{N}$ uptake at flowering. TSF: single $\mathrm{N}$ fertilization rate; VRF: variable N fertilization rate based on the optical sensor; PFP: grain yield partial factor; NAE: agronomic efficiency of N; NRE: N recovery efficiency; NPE: physiological $\mathrm{N}$ uptake efficiency; *: missing data.

table 3. The average PFP for sites 1 and 3 was higher than $70 \mathrm{~kg} \mathrm{~kg}^{-1}$. This value was suggested by Dobermann (2005) as critical for agricultural systems with good $\mathrm{N}$ management efficiency. The VRF showed an increase in PFP of 5.0, 7.0, and $8.2 \%$ at sites 1,2 and 3 , respectively, in relation to traditional TSF.

The VRF treatments had NAE 24.0 and $32.0 \%$ higher than TSF treatments at sites 1 and 3 , respectively. Site 2 had an increment of $8.3 \%$ by the use of VRF. A previous study with corn NF of $140 \mathrm{~kg} \mathrm{~N} \mathrm{ha}^{-1}$ showed NAE values ranging from 16 to $26 \mathrm{~kg} \mathrm{~kg}^{-1}$ (Melchiori et al., 2005). Dobermann (2005) reported that NAE values generally ranged from 10 to $30 \mathrm{~kg} \mathrm{~kg}^{-1}$, and values above $30 \mathrm{~kg} \mathrm{~kg}^{-1}$ represent well-managed agricultural systems. Thus, VRF promoted NAE values of 31 and $33 \mathrm{~kg} \mathrm{~kg}^{-1}$ at sites 1 and 3, respectively, indicating characteristics of an efficient $\mathrm{N}$ fertilization management.

The generally expected NRE values are between 0.3 and $0.5 \mathrm{~kg} \mathrm{~kg}^{-1}$, and those of well-managed $\mathrm{N}$ fertilization systems between 0.5 and $0.8 \mathrm{~kg} \mathrm{~kg}^{-1}$ (Dobermann, 2005). The average NRE at site 1 was $0.66 \mathrm{~kg} \mathrm{~kg}^{-1}$, indicating good efficiency of $\mathrm{N}$ fertilization, while site 3 had an intermediary $\left(0.44 \mathrm{~kg} \mathrm{~kg}^{-1}\right)$ and site $2 \mathrm{a}$ low value $\left(0.23 \mathrm{~kg} \mathrm{~kg}^{-1}\right)$.
The high NRE at site 1 was probably associated with the low aboveground dry matter production and $\mathrm{N}$ uptake until the phenological stage V8 of corn (Bragagnolo et al., 2013), which increases the probability of response to $\mathrm{N}$ topdressing. At site 1 , VRF increased NRE by $39.0 \%$ in relation to TSF. On the other hand, at site 3 , the VRF increased NRE by $43.7 \%$. For the NPE index, values between 30 and $60 \mathrm{~kg} \mathrm{~kg}^{-1}$ are generally reported, however in wellmanaged $\mathrm{N}$ fertilization systems, values should be higher than $60 \mathrm{~kg} \mathrm{~kg}^{-1}$ (Dobermann, 2005). The treatments 140TSF at sites 1 and treatments 140TSF, 140VRF, and 210TSF at site 3 were classified as wellmanaged systems, according to the critical values proposed by Dobermann (2005).

The use of the real-time crop sensor for the prescription of NF was a promising technique with regard to corn grain yield and NUE, especially when the climatic conditions were favorable to plant growth. Future research should evaluate larger sites than those investigated in this study, ensuring higher spatial variability. The combination of real-time crop sensors with new $\mathrm{N}$ fertilizer sources, which allow the reduction of $\mathrm{N}$ losses, should also be investigated as complementary strategies to improve NUE. 


\section{CONCLUSIONS}

1. At all investigated sites, the corn $\mathrm{N}$ uptake, dry matter production, and grain yield increased in response to $\mathrm{N}$ fertilization. However, lower increases in corn grain yield associated to $\mathrm{N}$ fertilization were noted at site 2 , due to the severe drought observed during the corn growing period.

2 . The $\mathrm{N}$ use efficiency assessed by different indices showed an improvement by the use of optical sensorbased variable fertilization rates in relation to the single-rate fertilization traditionally used by farmers.

3. Variable-rate fertilization, which improved the corn plant nutrition status (N uptake) did not increase corn grain yield in relation to single rate fertilization.

\section{ACKNOWLEDGEMENTS}

The authors are indebted to the partner companies STARA, MASSEY FERGUSON, YARA, and COTRIJAL in the Project Aquarius (www.ufsm.br/ projetoaquarius) for the technical support and for providing equipment for this study. They also wish to thank the National Council of Scientific and Technological Development (CNPq) for the scholarship of the second author and financial support to MCT/ CNPq 14/2010 - 480162/2010-7 and MCT/CNPq 14/ 2012 - 485896/2012-5, and CAPES for the scholarship of the first author.

\section{LITERATURE CITED}

AITA, C. \& GIACOMINI, S.J. Nitrato no solo com a aplicação de dejetos líquidos de suínos no milho em plantio direto. R. Bras. Ci. Solo, 32:195-205, 2008.

AMADO, T.J.C. \& MIELNICZUK, J. Leguminosas e adubação mineral como fontes de nitrogênio para o milho em sistemas de preparo do solo. R. Bras. Ci. Solo, 24:179-189, 2000.

AMADO, T.J.C.; MIELNICZUK, J. \& AITA, C. Recomendação de adubação nitrogenada para o milho no RS e SC adaptada ao uso de culturas de cobertura do solo, sob Sistema de Plantio Direto. R. Bras. Ci. Solo, 26:241-248, 2002.

ARGENTA, G.; SILVA, P.R.F.; FOSTHOFER, E.L.; STRIEDER, M.L.; SUHRE, E. \& TEICHMANN, L.L. Adubação nitrogenada em milho pelo monitoramento do nível de nitrogênio na planta por meio do clorofilômetro. R. Bras. Ci. Solo, 27:109-119, 2003.

BERNTSEN, J.; THOMSEN, A.; SCHELDE, K.; HANSEN, O.M.; KNUDSEN, K.; BROGE, N.; HOUGAARD, H. \& HØRFARTER, R. Algorithms for sensor-based redistribution of nitrogen fertilizer in winter wheat. Prec. Agric., 7:65-83, 2006.
BINDER, D.L.; SANDER, D.H. \& WALTERS, D.T. Maize response to time of nitrogen application as affected by level of nitrogen deficiency. Agron. J., 92:1228-1236, 2000.

BRAGAGNOLO, J; AMADO, T.J.C.; NICOLOSO, R.S.; JASPER, J.; KUNZ, J. \& TEIXEIRA, T.G. Optical crop sensor for variable-rate nitrogen fertilizaton in corn: I. Plant nutritien and dry matter production. R. Bras. Ci. Solo, 37:1288-1298. 2013.

CANTARELLA, H. Calagem e adubação de milho. In: BÜL, L.T. \& CANTARELLA, H., eds. Cultura do milho: Fatores que afetam a produtividade. Piracicaba, Potafos, 1993. p.147-198.

CANTARELLA, H.; TRIVELIN, P.C.O.; CONTIN, T.L.M.; DIAS, F.L.F.; ROSSETTO, R.; MARCELINO, R.; COIMBRA, R.B. \& QUAGGIO, J.A. Ammonia volatilization from urease inhibitor-treated urea applied to sugarcane trash blankets. Sci. Agric., 65:397-401, 2008.

CASA, R.; CAVAliERI, A. \& LOCASCIO, B. Nitrogen fertilization management in precision agriculture: a preliminary application example on maize. Ital. J. Agron., 6:23-27, 2011.

CERETTA, C.A.; BASSO, C.J.; VIEIRA, F.C.B.; HERBES, M.G.; MOREIRA, I.C.L. \& BERWANGER, A.L. Dejeto líquido de suínos: I. Perdas de nitrogênio e fósforo na solução escoada na superfície do solo, sob plantio direto. Ci. Rural, 35:1296-1304, 2005.

CIAMPITTI, I.A. \& GARCÍA, F.O. Balance y eficiencia de uso de los nutrientes en sistemas agrícolas. R. Horiz. A., 18:22$28,2008$.

COMISSÃO DE QUÍMICA E FERTILIDADE DO SOLO CQFSRS/SC. Recomendações de adubação e calagem para os estados do Rio Grande do Sul e Santa Catarina. 3.ed. Passo Fundo, SBCS - Núcleo Região Sul/ UFRGS, 2004. 400p.

COMPANHIA NACIONAL DE ABASTECIMENTO - CONAB. Acompanhamento da Safra Brasileira de Grãos 2008/2009. Available at: <http://www.conab.gov.br>. Accessed: June 10, 2009 .

COMPANHIA NACIONAL DE ABASTECIMENTO - CONAB. Acompanhamento da Safra Brasileira de Grãos 2010/2011. Available at: <http://www.conab.gov.br>. Accessed: Aug $15,2011$.

DOBERMANN, A. Nitrogen use efficiency - State of the art. In.: IFA INTERNATIONAL WORKSHOP ON ENHANCED-EFFICIENCY FERTILIZERS, Frankfurt, 2005. Proceedings... Frankfurt, 2005. p.28-30.

ESCOBAR, L.F.; AMADO, T.J.C.; BAYER, C.; CHAVEZ, L.F.; ZANATTA, J.A. \& FIORIN, J.E. Postharvest nitrous oxide emissions from a subtropical Oxisol as influenced by summer crop residues and their management. R. Bras. Ci. Solo, 34:507-516, 2010.

FANCELLI, A.L. \& DOURADO NETO, D. Milho: Fisiologia da produção. In: SEMINÁRIO SOBRE FISIOLOGIA DA PRODUÇÃO E MANEJO DE ÁGUA E DE NUTRIENTES NA CULTURA DO MILHO DE ALTA PRODUTIVIDADE. Piracicaba, ESALQ/USP - Potafos, 1996. p.1-29. 
FERNANDES, F.C.S. \& LIBARDI, P.L. Percentagem de recuperação de nitrogênio pelo milho, para diferentes doses e parcelamentos do fertilizante nitrogenado. R. Bras. Milho Sorgo, 6:285-296, 2007.

FERREIRA, D.F. Análises estatísticas por meio do Sisvar para Windows versão 4.0. In: REUNIÃO ANUAL DA REGIÃO BRASILEIRA DA SOCIEDADE INTERNACIONAL DE BIOMETRIA, 45., São Carlos, 2000. Anais... São Carlos, UFSCar, 2000. p.255-258.

FIORIN, J.E. Recomendação de adubação. In.: FIORIN, J.E., ed. Manejo e fertilidade do solo em sistema plantio direto. Passo Fundo, Berthier, 2007. p.51-89.

FONTOURA, S.M.V. \& BAYER, C. Ammonia volatilization in no-tillage system in the South-Central region of the State of Paraná, Brazil. R. Bras. Ci. Solo, 34:1677-1684, 2010.

GADIOLI, J.L.; DOURADO-NETO, D.; GARCÍA, A.G. \& BASANTA, M.D.V. Temperatura do ar, rendimento de grãos de milho e caracterização fenológica associada à soma calórica. Sci. Agric., 57:377-383, 2000.

GLAT, D. A dimensão do milho no mundo. Available at: <http:/ /www.agranja.com/index/revistas/agranja/edicao/738/ materia/2842>. Accessed: June. 30, 2010.

GREGORET, M.C.; DARDANELLI, J.; BONGIOVANNI, R. \& DIAZ-ZORITA, M. Modelo de respuesta sitio-específica del maíz al nitrógeno y agua edáfica en un haplusol. Ci. Suelo, 24:147-159, 2006.

JASPER, J.; REUSCH, S. \& LINK, A. Active sensing of the N status of wheat using optimized wavelength combinationimpact of seed rate, variety and growth stage. In: van HENTEN, E.; GOENSE, J.D. \& LOKHORST, C., eds. EUROPEAN CONFERENCE ON PRECISION AGRICULTURE, 7., Wageningen, 2009. Proceedings... Wageningen, Academic Publishers, 2009. p.23-30.

JØRGENSEN, J.R. \& JØRGENSEN, R.N. Uniformity of wheat yield and quality using sensor assisted application of nitrogen. Prec. Agric., 8:63-73, 2007.

JØRGENSEN, J.R. \& JØRGENSEN, R.N. Impact on grain quality parameters when nitrogen is 'sensor applied' by the 'Hydro Precise System'. "Precise system". In: GRENIER, G.S. \& BLACKMORE, S., eds. EUROPEAN CONFERENCE ON PRECISION AGRICULTURE. 3., Montpellier, 2001. Proceedings... Montpellier, 2001. p.929-934.

KANG, S.; GU, B.; DU, T. \& ZANG, J. Crop coefficient and ratio of transpiration to evapotranspiration of winter wheat and maize in a semi-humid region. Agric. Water Manage., 59:239-254, 2003.

LARA CABEZAS, W.A.R.; KORNDORFER, G.H. \& MOTTA, S.A. Volatilização de $\mathrm{N}-\mathrm{NH}_{3}$ na cultura de milho: I. Efeito da irrigação e substituição parcial da uréia por sulfato de amônio. R. Bras. Ci. Solo, 21:481-487, 1997b.

LARA CABEZAS, W.A.R.; KORNDORFER, G.H. \& MOTTA, S.A. Volatilização de $\mathrm{N}-\mathrm{NH}_{3}$ na cultura de milho: II. Avaliação de fontes sólidas e fluídas em sistema de plantio direto e convencional. R. Bras. Ci. Solo, 21:489-496, 1997a.

LI, Y.; CHEN, D.; WALKER, C.N. \& ANGUS, J.F. Estimating the nitrogen status of crops using a digital camera. Field Crops Res., 118:221-227, 2010.
MÂNICA, N. Available at: <http://mediacenter.clicrbs.com.br/ canal-rural-player/99/player/209409/mercado-e-cia-14-092011-gauchos-tecnificam-lavouras-e-conseguemaumentar-a-produtividade-das-safras-/1/index.htm>. Accessed: Oct 20, 2011.

MATZENAUER, R.; BERGAMASCHI, H.; BERLATO, M.A. \& RIBOLDI, J. Modelos agrometeorológicos para a estimativa do rendimento do milho, em função da disponibilidade hídrica no Estado do Rio Grande do Sul. Pesq. Agrop. Gaúcha, 1:225-241, 1995.

MAYFIELD, A.H. \& TRENGOVE, S.P. Grain and protein responses in wheat using the $\mathrm{N}$-Sensor for variable rate application. Crop Past. Sci., 60:818-823, 2009.

MELCHIORI, R.; CAVIGLIA, O.; BIANCHINI, A.; FACCENDINI, N. \& RAUN, W. Avances en la utilización de sensores remotos para manejo de nitrógeno de maíz. In: NATIONAL CONGRESSO OF AAPRESID, 14., Rosário, 2005. Proceedings... Rosário, 2005. p.155-160.

BRASIL. Ministério da Agricultura, Pecuária e Abastecimento. Cadeia produtiva do milho/Ministério da Agricultura, Pecuária e Abastecimento, Secretaria de Política Agrícola, Instituto Interamericano de Cooperação para a Agricultura. Brasília, IICA, MAPA/SPA, 2007. 108p.

PORTZ, G.; MOLIN, J.P. \& JASPER, J. Active crop sensor to detect variability of nitrogen supply and biomass on sugarcane fields. Prec. Agric., 13:33-44, 2012.

POVH, F.P. \& GIMENEZ, L.M. Aplicação de fertilizantes e corretivos em taxa variável. In: FONSECA, A.F.; CAIRES, E.F \& BARTH, G., eds. Fertilidade do solo e nutrição de plantas no sistema plantio direto. Ponta Grossa, 2011. p.217-247.

RAUN, W.R. \& JOHNSON, G.V. Improving nitrogen use efficiency for cereal production. Agron. J., 91:357-362, 1999.

RAUN, W.R.; SOLIE, J.B.; STONE, M.L.; MARTIN, K.L.; FREEMAN, K.W.; MULLEN, R.W.; ZHANG, H.; SHEPERS, J.S. \& JOHNSON, G.V. Optical sensor-based algorithm for crop nitrogen fertilization. Commun. Soil Sci. Plant Anal., 36:2759-2781, 2005.

ROJAS, C.A.L.; BAYER, C.; FONTOURA, S.M.V.; WEBER, M.A. \& VIEIRO, F. Volatilização de amônia da uréia alterada por sistemas de preparo de solo e plantas de cobertura invernais no Centro-Sul do Paraná. R. Bras. Ci. Solo, 36:261-270, 2012.

SANGOI, L.; ERNANI, P.R.; LECH, V.A. \& RAMPAZZO, C. Lixiviação de nitrogênio afetada pela forma de aplicação da uréia e manejo dos restos culturais de aveia em dois solos com texturas contrastantes. Ci. Rural, 33:65-70, 2003.

SARAIVA, A.M.; CUGNASCA, C.E. \& HIRAKAWA, A.R. Aplicação em taxa variável de fertilizantes e sementes. In: BORÉM, A.; GIÚDICE, M.P.; QUEIROZ, D.M.; MANTOVANI, E.C.; FERREIRA, L.R.; VALLE, F.X.R. \& GOMIDE, R.L., eds. Agricultura de precisão. Viçosa, MG, Universidade Federal de Viçosa, 2006. p.109-145.

SHAHANDEH, H.; WRIGHT, A.L.; HONS, F.M. \& LASCANO, R.J. Spatial and temporal variation of soil nitrogen parameters related to soil texture and corn yield. Agron. J., 97:772-782, 2005. 
SINGH, I.; SRIVASTAVA, I.A.; CHANDNA, P. \& GUPTA, R. Crop sensors for efficient nitrogen management in sugarcane: Potential and constraints. Sugar Technol., 8:299-302, 2006.

SODERSTROM, M.; BORJESSON, T.; PETTERSSON, C.G.; NISSEN, K. \& HAGNER, O. Prediction of protein content in malting barley using proximal and remote sensing. Prec. Agric., 11:587-599, 2010.

SOLIE, J.B.; RAUN, W.R. \& STONE, M.L. Submeter spatial variability of selected soil and bermudagrass production variables. Soil Sci. Soc. Am. J., 63:1724-1733, 1999.
TREMBLAY, N.; WANG, Z.; MA, B.L.; BELEC, C. \& VIGNEAULT, P. A comparison of crop data measured by two commercial sensors for variable-rate nitrogen application. Prec. Agric., 10:145-161, 2009.

WARRICK, A.W. \& NIELSEN, D.R. Spatial variability of soil physical properties in the field. In: HILLEL, D., ed. Applications of soil physics. New York, Academic Press, 1980. p.319-344.

YARA. Operation manual for the Yara N-Sensor. Software release 3.00. Dülmen, Research Center Hanninghof, 2008. $55 \mathrm{p}$. 